\title{
Management of Damping-Off and Root- \\ Rot Diseases of Faba bean by \\ Bioproducts and Inducer Resistance \\ Chemicals
}

Sahar A. El-Sayed

Plant Pathol. Res. Inst., A.R.C., Egypt.

\begin{abstract}
This study was carried out to evaluate the efficiency of Plant Guard 1 (Trichoderma harzianum) and Rhizo-N (Bacillus subtilis ) as bioproducts in combination with ascorbic and shikimic acid as inducer resistance chemicals in management of faba bean damping-off and rootrot diseases caused by Fusarium moniliforme, F. solani and Macrphomina phaseolina under greenhouse and field conditions. In vitro using the tested two bioagents as well as the two inducer resistance chemicals (IRCs) and the fungicide Rizolex-T, significantly reduced the linear growth of the tested three pathogenic fungi. Rizolex-T followed by $T$. harzianum then ascorbic acid were the most effective treatments in reducing the linear growth of the tested fungi. Meanwhile, shikimic acid followed by $B$. subtilis were the lowest efficient ones in this regard. Under greenhouse conditions, soaking faba bean seeds in ascorbic acid then coating with Plant Guard (after adding talc powder) or Rhizo-N were the most effective treatments in managing the tested fungi. However, dressing faba bean seeds with the fungicide Rizolex-T was the superior treatment in this regard. In field experiments, soaking faba bean seeds in ascorbic or shikimic acid then coating with Plant Guard were the most effective treatments in reducing the natural infection by dampingoff and root-rot diseases. Moreover, these treatments improved the estimated crop parameters as well as increased the percentages of total nitrogen and protein constitute of the dry seeds compared with the control treatment. Also, dressing faba bean seeds with the fungicide Rizolex-T was the superior treatment in this respect.
\end{abstract}

Keywords: Biological control, damping-off, faba bean, inducer resistance chemical, protein constitute and root-rot.

Faba bean (Vicia faba L.) is used as an important human food in developing countries and as an animal feed mainly for pigs, horses, poultry and pigeons in industrialized countries. Feeding value of faba bean is high and this legume has been considered as a meat extender or substitute due to its high protein content (20 - 41\%) (Chavan et al., 1989). However, soil-borne plant pathogens are the main threat for its profitable productivity.

Hammerschmidt (1999) mentioned that plant defence mechanisms are both constitutive and inducible. The former include the physical barriers opposing pathogen penetration and the pre-formed antibiotic or biostatic compounds, while the latter involve de novo synthesized products, such as new material apposition, active anti-microbial chemicals and pathogenesis-related proteins. 
Singh et al. (2012) mentioned that nitrogen fixed by roots of faba bean plants results in increasing residual soil nitrogen for subsequent crops. It can also be used as green manure which has potential to fix free nitrogen at 150 to $300 \mathrm{~kg} \mathrm{~N}$ ha- 1 . Faba bean is seen as an agronomical viable alternative to cereal grains. It is a good source of lysine rich protein as well as levodopa (L-3,4-dihydroxyphenylalanine (Ldopa)). Levodopa, a precursor of dopamine, can be potentially used as medicine for the treatment of Parkinson's disease. It is also a natriuretic agent, which might help in controlling hypertension. Persons consuming faba bean may suffer from favism (type of anaemia) if they lack an enzyme called glucose-6-phosphatage dehydrogenase (G6PD).

Damping-off, root-rot and wilt diseases caused by several soil-borne fungal pathogens are wide spread and serious in many crops cultivated in different soil types. Several root-rot and wilt pathogens such as Rhizoctonia solani, Fusarium solani and Macrophomina phaseolina are reported to attack faba bean roots and stem base causing serious losses in seed germination and plant stand as well seed yield (Abdel-Kader et al., 2011). Moreover, seeds of faba bean can be contaminated by mycotoxins secreted by some fungi grown on these seeds. Mycotoxins attract worldwide attention because of the significant economic losses associated with their impact on human health, animal productivity and trade (Khlangwiset et al., 2011).

Management of plant diseases is important for most crops, and it is particularly critical for the production of high-quality seeds. Plant pathogens can reduce the quantity and quality of the harvested seeds and in additions they can be preserved in seed lots in the case of seed-borne pathogens. In this way, seeds can inadvertently provide an efficient means of plant pathogen dissemination (Abdel Monaim, 2013 and Mancini and Romanazzi, 2014). Coating seeds of many crops with biocontrol agents such Trichoderma spp., Bacillus subtilis, Pseudomonas fluorescens was one of the most effective treatments for controlling seed and root-rot pathogens (Nayaka et al., 2004 and Begum et al., 2011). However, El-Mohamedy and Abd-Alla (2013) and El-Mohamedy et al. (2015) reported that practical using of bio-priming seed treatment to control root-rot soil-borne plant pathogens as a substitute of chemical fungicides is possible without any risk to human, animal and the environment. Biological control of soil-borne pathogens is often attributed to improve nutrition that boosts host defense or to direct inhibition of pathogen growth and activity. Amendment with certain abiotic factor (inducers) appears to stimulate the disease resistance by indirectly stimulating indigenous populations of microorganism that are beneficial to plant growth and antagonistic to pathogens. For example chitin amendment of soil has been found to stimulate the growth of chitinolytic microorganisms (De Boer et al., 1999), increase the bio-control activity and stimulate the expression of plant defense proteins (Roby et al., 1987 and Muthami et al., 2007). All these effects may culminate in enhancing plant protection. Similarly, salicylic acid (SA) and $\mathrm{H}_{2} \mathrm{O}_{2}$ amendment was tested in combination with bioagents. Saikia et al. (2003) tested the efficiency of $P$. fluorescens with or without SA amendment in chickpea against Fusarium wilt infection. The application of $P$. fluorescens (Pf4-92) with SA recorded the highest protection of chickpea seedlings against wilt disease.

Egypt. J. Phytopathol., Vol. 45, No. 1 (2017) 
The objective of this research is to evaluate the inhibitory effect of two bioproducts and two inducer resistance chemicals (IRCs) on the linear growth of Fusarium moniliforme, F. solani and Macrphomina phaseolina responsible for causing faba bean damping-off and root-rot diseases. Also, to evaluate these materials as alternatives for managing damping-off and root-rot diseases of faba bean under greenhouse and field conditions. The work was expanded to assess the effect of these treatments on some crop parameters of faba bean plants, percentage of total nitrogen and protein constitute of dry seeds in field experiments.

\section{Materials and Methods}

\section{Source of the pathogens:}

Virulent isolates of $F$. moniliforme, F. solani and Macrphomina phaseolina, previously isolated from faba bean roots, were obtained from Legume Dis. Dept., Plant Pathol. Res. Inst., ARC.

\section{Source of the bioagents:}

Two commercial bioproducts, i.e. Rhizo-N (Bacillus subtilis $3 \times 10^{7} \mathrm{cfu} / \mathrm{ml}$ and Plant Guard (Trichoderma harzianum, $3 \times 10^{7} \mathrm{cfu} / \mathrm{ml}$ ), were used. Loops from each product were streaked on nutrient agar and PDA media, respectively to obtain the bioagent of each product and maintained in slants contained nutrient agar and PDA medium, respectively.

\section{Source of faba bean seeds:}

Faba bean seeds cv. Giza 429 were obtained from Crops Res. Inst., ARC, Giza.

4. Effect of the tested bioagents, IRCs and the fungicide Rizolex-T on the linear growth of the tested fungi:

This experiment was conducted to evaluate the effect of T. harzianum, $B$. subtilis, ascorbic acid (vitamin-c) and shikimic acid (phenolic compound) and the fungicide Rizolex-T 50\% (Tolclfus-methyl) on the linear growth of F. moniliforme, $F$. solani and $M$. phaseolina. In this respect, Petri-plates containing PDA medium were inoculated with a disc ( $5 \mathrm{~mm}$ in diameter) taken from 7 days-old cultures of the pathogenic fungi. The pathogenic fungi were inoculated at one side of the Petridish at $5 \mathrm{~mm}$ a part, whereas the opposite side was inoculated with $T$. harzianum. Meanwhile in case of $B$. subtilis, the pathogenic fungi were inoculated at the sides of the Petri-dish at $5 \mathrm{~mm}$ a part and B. subtilis was streaked in the center of the Petri-dish.

The IRCs, i.e. ascorbic acid and shikimic acid (at $8 \mathrm{mM}$ ) as well as Rizolex-T were added to PDA medium after sterilization (at $250 \mathrm{ppm}$ ). Petri-dishes were inoculated with $5 \mathrm{~mm}$ disks for 7 days-old fungal culture. Petri-dishes containing PDA only were inoculated with the tested fungi only were used as control. Three replicates were used for each treatment and the control. All previous plates were incubated at $25 \pm 1^{\circ} \mathrm{C}$ for 5 days then examined. Percentages of reduction in fungal growth were calculated as the growth in different treatments relative to those in check treatment. 
5. Seed soaking in the IRCs:

Disinfected faba-been seeds were soaked for $12 \mathrm{~h}$ in any of the tested IRCs (ascorbic and shikimic acid) at $8 \mathrm{mM}$ just before sowing or before coating with the two tested commercial bioproducts.

6. Preparation of Plant Guard as powder:

Plant Guard was mixed with sterilized talc powder at the rate of 1:1 (v/w), then dried at room temperature and kept in a refrigerator at $10^{\circ} \mathrm{C}$ until usage .

\section{Seed coating with the bioproducts:}

Faba bean cv. Giza 429 was sprayed with $1 \%$ Triton-B as sticker after soaking in the IRCs then coated with the two commercial bioproducts each alone, i.e. Plant Guard $\left(T\right.$. harzianum $3 \times 10^{7} \mathrm{cfu} / \mathrm{ml}$ ) and Rhizo-N (Bacillus subtilis, $3 \times 10^{7}$ $\mathrm{cfu} / \mathrm{ml})$ at the rate of $4.0 \mathrm{~g} / \mathrm{kg}$ seed and left to air dry then sown.

8. Seed dressing with the fungicide:

Faba bean seeds sprayed with $1 \%$ Triton-B as sticker were dressed with Rizolex-T $50 \%$ at the recommended dose $(3 \mathrm{~g} / \mathrm{kg}$ seeds $)$ then sown in pots filled with the infested soil with the tested fungi and also in the field under the natural soil infestation.

9. Effect of the tested bioproducts, IRCs and the fungicide Rizolex-T on the incidence of damping-off and root-rot severity under greenhouse conditions:

This experiment was carried out to evaluate the efficiency of different seed treatments, i.e. Rhizo-N, Plant Guard, ascorbic and shikimic acid, each alone and in combinations, i.e. ascorbic acid $+T$. harzianum, shikimic acid $+T$. harzianum, asorbic acid $+B$. subtilis, shikimic acid $+B$. subtilis on the incidence of dampingoff and root-rot severity under greenhouse conditions in comparison with the fungicide Rizolex-T (positive control) and untreated seeds (negative control).

Formalin disinfested loamy soil was infested with $2 \%$ inoculum level of any of $F$. moniliforme, $F$. solani and $M$. phaseolina, grown on autoclaved barley medium in 500 glass bottles. The infested soil was distributed in plastic pots $(25 \mathrm{~cm}$ in diameter) and irrigated one week before sowing the seeds. Faba bean seeds (cv. Giza 429) were treated with the following treatments just before sowing:

1- Coating with Rhizo-N at the rate of $4 \mathrm{~g} / \mathrm{kg}$ seed.

2- Coating with Plant Guard at the rate of $4 \mathrm{~g} / \mathrm{kg}$ seed.

3- Soaking in ascorbic acid ( $8 \mathrm{mM})$ for twelve hrs.

4- Soaking in shikimic acid $(8 \mathrm{mM})$ for twelve hrs.

5- Soaking in ascorbic acid $(8 \mathrm{mM})$ for twelve hrs. then coating with Rhizo-N at the rate of $4 \mathrm{~g} . / \mathrm{kg}$. seeds.

6- Soaking in shikimic acid $(8 \mathrm{mM})$ for twelve hrs, then coating with Plant Guard at the rate of $4 \mathrm{glkg}$. seeds.

7- Dressing with the fungicide Rizolex-T at the rate of $3 g / k g$ seed (positive control)

8- Untreated seeds with any material. 
Five faba bean seeds of any of the aforementioned treatments were sown in each pot and six pots were used as a particular treatment. Disease incidence was recorded as the percentages of pre- and post-emergence damping-off, as well as survived plants 15, 30 and 45 days after sowing, respectively .Also, root-rot severity was assessed 60 days after sowing using the devised scale (0-5\%) according to Salt (1982) as follows:

$$
\text { Root-rot severity } \%=\frac{\text { Sum of }(\mathrm{nxv})}{5 \mathrm{~N}} \times 100
$$

Where:

$\mathrm{n}=$ Number of roots in each category,

$\mathrm{v}=$ Numerical value of each category,

$\mathrm{N}=$ Total number of roots in the samples.

\section{Field experiments:}

Field experiments were carried out at Sers El-Lyain Res. Stat., Menoufia governorate, Egypt during two successive growing seasons (2014/2015 and $2015 / 2016$ ), in a piece of land has a back history of high infestation with soil-borne pathogens responsible for causing damping-off and root-rot diseases of faba bean . The experiment aimed to study the effect of: a) Single treatments: seeds coated with Plant Guard and Rhizo-N, seeds soaked in ascorbic and Shikimic acid, b) Combined treatments: ascorbic acid + Plant Guard, ascorbic acid + Rhizo-N, shikimic acid + Plant Guard, shikimic acid + Rhizo-N ., c) Seeds dressed with the fungicide Rizolex-T $50 \%$ and d) Control (untreated seeds).

The field was divided into plots of $10.5 \mathrm{~m}^{2}(3.5 \times 3 \mathrm{~m})$ with 8 rows of $3 \mathrm{~m}$. long. The treated seeds with the aforementioned treatments were sown at the rate of two seeds in each hill with $25 \mathrm{~cm}$. between the two hills on one side of the row. Complete Randomized Block Design with three replicates (plots) for each particular treatment was done.

The incidence of pre- and post-emergence damping-off was determined 15 and 30 days after sowing. Also, the survived plants were counted 45 days after sowing. Sixty days after sowing, ten randomized plants were gently pulled-off, 5 days after irrigation to assess the severity of root-rot as mentioned before. In addition, some crop parameters, i.e. plant height, number of branches/plant, number of pods/plant, weight of 100 seeds and weight of seed yield/plot were assessed.

11. Effect of the tested bioproducts, the IRCs and the fungicide Rizolex-T on chemical quality of faba bean seeds:

Random samples of faba bean pods were taken from the yield of each treatment in each growing season and the following chemical analysis were determined. The percentage of nitrogen in the seeds was determined according to the method described by Hafez and Mikkelsen (1981). In addition, protein percentage was calculated by multiplying nitrogen content by 6.25 .

\section{Statistical analysis:}

All the obtained data were subjected to the proper statistical analysis of variance (ANOVA) of randomized complete block design (Gomez and Gomez, 1984). 


\section{Res u l t s}

Effect of the tested bioproducts, IRCs and the fungicide Rizolex-T on the linear growth of the tested fungi in vitro:

The effect of the tested bioagents, IRCs and the fungicide Rizolex-T on the linear growth of $F$. moniliforme, $F$. solani and $M$. phaseolina, the causal of damping-off and root-rot of faba bean is shown in Table 1. Data indicate that all treatments significantly reduced the linear growth of the tested fungi. The tested fungi failed to grow at $250 \mathrm{ppm}$. of the fungicide Rizolex-T. The average linear growth of the tested fungi recorded 35.8, 37.4, 41.9 and $43.4 \mathrm{~mm}$. when B. subtilis, T. harzianum, shikimic acid and ascorbic acid were tested, respectively. In addition, the linear growth of the fungus $F$. solani was the most affected by the tested materials followed by $F$. moniliforme then $M$. phaseoina, being 38.0, 41.4 and 44.9 $\mathrm{mm}$, respectively.

Table 1. Effect of two bioagents and IRCs as well as the fungicide Rizolex-T on the linear growth of $F$. moniliforme, $F$. solani and $M$. phaseolina grown on PDA medium, 5 days after incubation at $25 \pm 1^{\circ} \mathrm{C}$

\begin{tabular}{|l|cc|c|c|}
\hline \multicolumn{1}{|c|}{ Treatments } & \multicolumn{3}{|c|}{ Average linear growth (mm) of } & Mean \\
& F. moniliforme & F. solani & M. phaseolina & \\
\hline \hline B. subtilis & 35.0 & 32.0 & 40.3 & 35.8 \\
T. harzianum & 38.3 & 30.0 & 44.0 & 37.4 \\
Ascorbic acid & 45.0 & 35.3 & 50.0 & 43.4 \\
Shikimic acid & 40.0 & 40.7 & 45.0 & 41.9 \\
Rizolex-T & 0.0 & 0.0 & 0.0 & 0.0 \\
Control & 90.0 & 90.0 & 90.0 & 90.0 \\
\hline \hline \multicolumn{1}{|c|}{ Mean } & 41.4 & 38.0 & 44.9 & ---- \\
\hline
\end{tabular}

L.S.D. at $5 \%$ for: Treatment $(\mathrm{T})=3.1$, Linear growth $(\mathrm{L})=2.2$ and $\mathrm{TxL}=4.3$.

Effect of the tested IRCs, bioproducts and the fungicide Rizolex-T on the incidence of faba bean damping-off and root-rot severity caused by the tested fungi under greenhouse conditions:

The effect of different seed treatments on managing of damping-off and root-rot severity caused by the main root-rot pathogens ( $F$. moniliforme, $F$. solani and $M$. phaseolina) of faba bean was evaluated under greenhouse conditions. Results shown in Tables $2 \mathrm{a}, \mathrm{b}$ and $\mathrm{c}$ show that, in general, all the tested seed treatments, i.e. IRCs, bioproducts and the fungicide Rizolex-T significantly decreased pre- and post-emergence damping-off as well as root-rot severity caused by the three tested fungi compared to the control treatment. The fungicide Rizolex-T was the superior treatment in this regard. However, the combined treatments between any of the two IRCs (ascorbic and shikimic acid) or the two bioproducts (Plant Guard and Rhizo$\mathrm{N}$ ) caused great reduction to both damping-off and root-rot severity. In addition, the combination between ascorbic acid and Plant Guard was the most efficient combination in reducing pre- and post-emergence damping-off and root-rot severity caused by any of the three tested fungi, being $6.7,10.0$ and $18.9 \%$ for

Egypt. J. Phytopathol., Vol. 45, No. 1 (2017) 
F. moniliforme; $10.0,10.0$ and $22.2 \%$ for $F$. solani; $13.3,10.0$ and $27.3 \%$ for $M$. phaseolina, respectively. Furthermore, both $F$. moniliforme and $F$. solani were greatly affected by the tested treatments than $M$. phaseolina. On the other hand, the lowest effect was occurred due to using seeds coated with Rhizo-N followed by seeds soaked in shikimic acid.

Table 2a. Effect of the tested IRCs, bioagents and the fungicide Rizolex-T on the incidence of damping-off and root-rot severity of faba bean caused by $F$. moniliforme under greenhouse conditions

\begin{tabular}{|c|c|c|c|c|}
\hline \multirow[b]{3}{*}{ Treatment } & \multicolumn{4}{|c|}{ F. moniliforme } \\
\hline & \multicolumn{2}{|c|}{$\%$ Damping-off } & \multirow[b]{2}{*}{$\begin{array}{c}\% \\
\text { Survived } \\
\text { plants }\end{array}$} & \multirow[b]{2}{*}{$\begin{array}{c}\% \\
\text { Root-rot } \\
\text { severity }\end{array}$} \\
\hline & 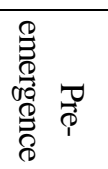 & 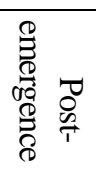 & & \\
\hline Seeds soaked in ascorbic acid & 10.00 & 13.3 & 76.7 & 25.6 \\
\hline Seeds soaked in shikimic acid & 13.3 & 16.6 & 70.0 & 32.2 \\
\hline Seeds coated with Plant Guard & 13.3 & 13.3 & 73.3 & 30.0 \\
\hline Seeds coated with Rhizo-N & 16.7 & 13.3 & 70.00 & 28.6 \\
\hline $\begin{array}{l}\text { Seeds soaked in ascorbic acid and coated } \\
\text { with Plant Guard }\end{array}$ & 6.7 & 10.0 & 83.3 & 18.9 \\
\hline $\begin{array}{l}\text { Seeds soaked in ascorbic acid and coated } \\
\text { with Rhizo-N }\end{array}$ & 10.0 & 10.0 & 80.0 & 20.0 \\
\hline $\begin{array}{l}\text { Seeds soaked in shikimic acid and coated } \\
\text { with Plant Guard }\end{array}$ & 10.0 & 13.3 & 76.7 & 27.3 \\
\hline $\begin{array}{l}\text { Seeds soaked in shikimic acid and coated } \\
\text { with Rhizo-N }\end{array}$ & 13.3 & 13.3 & 73.3 & 28.6 \\
\hline Seeds dressed with the fungicide Rizolex-T & 3.3 & 0.0 & 96.7 & 6.7 \\
\hline Control (untreated) & 26.7 & 22.0 & 51.3 & 53.3 \\
\hline L.S.D at $5 \%$ & 2.8 & 2.6 & 4.0 & 3.3 \\
\hline
\end{tabular}


Table 2b. Effect of the tested IRCs, bioagents and the fungicide Rizolex-T on the incidence of damping-off and root-rot severity of faba bean caused by $F$. solani under greenhouse conditions

\begin{tabular}{|c|c|c|c|c|}
\hline \multirow[b]{3}{*}{ Treatment } & \multicolumn{4}{|c|}{ F. solani } \\
\hline & \multicolumn{2}{|c|}{$\begin{array}{l}\text { \% Damping- } \\
\text { off }\end{array}$} & \multirow{2}{*}{$\begin{array}{c}\% \\
\text { Survived } \\
\text { plants }\end{array}$} & \multirow{2}{*}{$\begin{array}{c}\% \\
\text { Root-rot } \\
\text { severity }\end{array}$} \\
\hline & 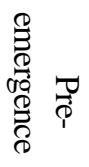 & 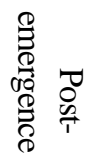 & & \\
\hline Seeds soaked in ascorbic acid & 13.3 & 16.7 & 70.00 & 30.0 \\
\hline Seeds soaked in shikimic acid & 16.7 & 20.00 & 63.3 & 35.3 \\
\hline Seeds coated with Plant Guard & 13.3 & 16.7 & 70.0 & 28.9 \\
\hline Seeds coated with Rhizo-N & 20.0 & 13.3 & 66.7 & 33.3 \\
\hline $\begin{array}{l}\text { Seeds soaked in ascorbic acid and coated } \\
\text { with Plant Guard }\end{array}$ & 10.0 & 10.0 & 80.0 & 22.2 \\
\hline $\begin{array}{l}\text { Seeds soaked in ascorbic acid and coated } \\
\text { with Rhizo-N }\end{array}$ & 13.3 & 10.0 & 76.7 & 25.6 \\
\hline $\begin{array}{l}\text { Seeds soaked in shikimic acid and coated } \\
\text { with Plant Guard }\end{array}$ & 13.3 & 13.3 & 73.7 & 27.3 \\
\hline $\begin{array}{l}\text { Seeds soaked in shikimic acid and coated } \\
\text { with Rhizo-N }\end{array}$ & 13.3 & 16.7 & 70.0 & 30.6 \\
\hline Seeds dressed with the fungicide Rizolex-T & 3.3 & 3.3 & 93.3 & 8.9 \\
\hline Control (untreated) & 30.0 & 26.7 & 43.3 & 58.6 \\
\hline L.S.D at $5 \%$ & 3.0 & 2.8 & 4.3 & 2.5 \\
\hline
\end{tabular}


Table 2c. Effect of the tested IRCs, bioagents and the fungicide Rizolex-T on the incidence of damping-off and root-rot severity of faba bean caused by M. phaseolina under greenhouse conditions

\begin{tabular}{|c|c|c|c|c|}
\hline \multirow{3}{*}{ Treatment } & \multicolumn{4}{|c|}{ M. phaseolina } \\
\hline & \multicolumn{2}{|c|}{$\%$ Damping-off } & \multirow{2}{*}{$\begin{array}{c}\% \\
\text { Survived } \\
\text { plants }\end{array}$} & \multirow{2}{*}{$\begin{array}{c}\% \\
\text { Root- } \\
\text { rot } \\
\text { severity }\end{array}$} \\
\hline & $\begin{array}{c}\text { Pre- } \\
\text { emergence }\end{array}$ & $\begin{array}{c}\text { Post- } \\
\text { emergence }\end{array}$ & & \\
\hline Seeds soaked in ascorbic acid & 16.7 & 16.7 & 66.7 & 35.3 \\
\hline Seeds soaked in shikimic acid & 20.0 & 20.0 & 60.0 & 39.6 \\
\hline Seeds coated with Plant Guard & 16.7 & 13.3 & 70.0 & 30.0 \\
\hline Seeds coated with Rhizo-N & 16.7 & 16.7 & 66.7 & 33.6 \\
\hline $\begin{array}{l}\text { Seeds soaked in ascorbic acid and } \\
\text { coated with Plant Guard }\end{array}$ & 13.3 & 10.0 & 76.7 & 27.3 \\
\hline $\begin{array}{l}\text { Seeds soaked in ascorbic acid and } \\
\text { coated with Rhizo-N }\end{array}$ & 16.7 & 10.0 & 73.3 & 28.6 \\
\hline $\begin{array}{l}\text { Seeds soaked in shikimic acid and } \\
\text { coated with Plant Guard }\end{array}$ & 13.3 & 16.7 & 70.0 & 32.2 \\
\hline $\begin{array}{l}\text { Seeds soaked in shikimic acid and } \\
\text { coated with Rhizo-N }\end{array}$ & 16.7 & 20.0 & 63.3 & 37.3 \\
\hline $\begin{array}{l}\text { Seeds dressed with the fungicide } \\
\text { Rizolex-T }\end{array}$ & 6.6 & 3.3 & 90.0 & 11.6 \\
\hline Control (untreated) & 33.3 & 26.7 & 40.0 & 62.2 \\
\hline L.S.D at $5 \%$ & 2.5 & 2.4 & 3.4 & 2.3 \\
\hline
\end{tabular}

Effect of treatment faba bean seeds with the IRCs, bioproducts and Rizolex-T on the incidence of damping-off and root-rot severity under field conditions:

The effect of the two IRCs, bioproducts and Rizolex-T on the incidence of damping-off and root-rot severity is presented in Tables $3 \mathrm{a}$ and $\mathrm{b}$. The obtained results reveal that these treatments significantly reduced pre- and post-emergence damping-off and root-rot severity compared to the untreated plants (control). Rizolex-T resulted in the highest level of disease reduction with the highest values of survived plants compared to the check treatment. Moreover, Rizolex-T gave the best results in decreasing the percentages of pre- and post-emergence damping-off and root-rot severity during the two growing seasons. Shikimic acid was the lowest effective treatment in this regard. 
Table 3a. Effect of the tested IRCs, bioproduts and the fungicide Rizolex-T on the incidence of damping-off and root-rot severity of fabe bean under field conditions during 2014/2015 growing season

\begin{tabular}{|c|c|c|c|c|}
\hline \multirow[b]{3}{*}{ Treatment } & \multicolumn{4}{|c|}{$2014 / 2015$} \\
\hline & \multicolumn{2}{|c|}{ \% Damping-off } & \multirow{2}{*}{$\begin{array}{c}\% \\
\text { Survived } \\
\text { plants }\end{array}$} & \multirow{2}{*}{$\begin{array}{c}\% \\
\text { Root-rot } \\
\text { severity }\end{array}$} \\
\hline & $\begin{array}{c}\text { Pre- } \\
\text { emergence }\end{array}$ & $\begin{array}{c}\text { Post- } \\
\text { emergence }\end{array}$ & & \\
\hline Seeds soaked in ascorbic acid & 10.0 & 11.0 & 79.0 & 15.6 \\
\hline Seeds soaked in shikimic acid & 11.3 & 12.7 & 76.0 & 0.0 \\
\hline Seeds coated with Plant Guard & 9.1 & 10.0 & 80.9 & 16.7 \\
\hline Seeds coated with Rhizo-N & 10.1 & 1.3 & 78.6 & 18.9 \\
\hline $\begin{array}{l}\text { Seeds soaked in ascorbic acid and } \\
\text { coated with Plant Guard }\end{array}$ & 6.2 & 7.2 & 86.6 & 11.1 \\
\hline $\begin{array}{l}\text { Seeds soaked in ascorbic acid and } \\
\text { coated with Rhizo-N }\end{array}$ & 8.2 & 9.4 & 82.4 & 12.2 \\
\hline $\begin{array}{l}\text { Seeds soaked in shikimic acid } \\
\text { and coated with Plant Guard }\end{array}$ & 7.2 & 8.1 & 84.7 & 13.3 \\
\hline $\begin{array}{l}\text { Seeds soaked in shikimic acid } \\
\text { and coated with Rhizo-N }\end{array}$ & 9.2 & 9.5 & 81.3 & 14.4 \\
\hline $\begin{array}{l}\text { Seeds dressed with the fungicide } \\
\text { Rizolex-T }\end{array}$ & 00.0 & 3.3 & 96.7 & 6.7 \\
\hline Control (untreated) & 26.2 & 20.0 & 53.8 & 40.2 \\
\hline L.S.D at $5 \%$ & 7.3 & 7.5 & 11.71 & 1.8 \\
\hline
\end{tabular}


Table 3b. Effect of the tested IRCs, bioagents and the fungicide Rizolex-T on the incidence of damping-off and root-rot severity of fabe bean under field conditions during 2015/2016 growing seasons

\begin{tabular}{|c|c|c|c|c|}
\hline \multirow[b]{3}{*}{ Treatment } & \multicolumn{4}{|c|}{$2015 / 2016$} \\
\hline & \multicolumn{2}{|c|}{ \% Damping-off } & \multirow{2}{*}{$\begin{array}{c}\% \\
\text { Survived } \\
\text { plants }\end{array}$} & \multirow{2}{*}{$\begin{array}{c}\% \\
\text { Root-rot } \\
\text { severity }\end{array}$} \\
\hline & $\begin{array}{c}\text { Pre- } \\
\text { emergence }\end{array}$ & $\begin{array}{c}\text { Post- } \\
\text { emergence }\end{array}$ & & \\
\hline Seeds soaked in ascorbic acid & 10.2 & 11.0 & 78.8 & 20.0 \\
\hline Seeds soaked in shikimic acid & 11.5 & 12.0 & 76.5 & 22.2 \\
\hline Seeds coated with Plant Guard & 9.5 & 11.0 & 79.5 & 18.9 \\
\hline Seeds coated with Rhizo-N & 10.9 & 12.0 & 77.1 & 20.0 \\
\hline $\begin{array}{l}\text { Seeds soaked in ascorbic acid and } \\
\text { coated with Plant Guard }\end{array}$ & 7.0 & 8.0 & 85.0 & 12.2 \\
\hline $\begin{array}{l}\text { Seeds soaked in ascorbic acid and } \\
\text { coated with Rhizo-N }\end{array}$ & 8.1 & 9.0 & 82.9 & 13.3 \\
\hline $\begin{array}{l}\text { Seeds soaked in shikimic acid and } \\
\text { coated with Plant Guard }\end{array}$ & 7.9 & 8.0 & 84.1 & 15.6 \\
\hline $\begin{array}{l}\text { Seeds soaked in shikimic acid and } \\
\text { coated with Rhizo-N }\end{array}$ & 8.8 & 9.2 & 82.0 & 17.8 \\
\hline $\begin{array}{l}\text { Seeds dressed with the fungicide } \\
\text { Rizolex-T }\end{array}$ & 3.3 & 3.3 & 93.7 & 8.9 \\
\hline Control (untreated) & 27.9 & 22.1 & 50.0 & 44.1 \\
\hline L.S.D at $5 \%$ & 7.0 & 8.1 & 12.8 & 2.0 \\
\hline
\end{tabular}

Effect of the tested IRCs, bioproducts and Rizolex-T on growth and crop components of faba bean under field conditions:

The effect of treating faba bean seeds with the tested IRCs, bioproducts and Rizolex-T on some crop parameters under field conditions was assessed during 2014-2015 and 2015-2016 growing seasons. Data in Tables 4a and b indicate that the combination between the bioproducts and the IRCs resulted in considerable improve to faba bean growth and branching more than using each of them individually. The combination between ascorbic acid and Plant Guard was the most effective treatment, where recorded the highest plant height and number of branches in both seasons as well as recorded the highest yield components, i.e. number of pods/plant, weight of 100 seeds and total yield ( $\mathrm{kg} / \mathrm{plot})$ in both seasons. 
Table 4a. Effect of the tested bioagents, IRCs and the fungicide Rizolex-T on some growth and crop parameters of faba bean plants under field conditions during 2014/2015 growing seasons

\begin{tabular}{|l|l|l|l|l|c|}
\hline \multicolumn{1}{|c|}{ Treatment } & $\begin{array}{l}\text { Plant } \\
\text { height } \\
(\mathrm{cm})\end{array}$ & $\begin{array}{c}\text { No. of } \\
\text { branches } \\
\text { / plant }\end{array}$ & $\begin{array}{c}\text { No. of } \\
\text { Pods/ } \\
\text { plant }\end{array}$ & $\begin{array}{c}100 \\
\text { seeds } \\
\text { (w/g) }\end{array}$ & $\begin{array}{c}\text { Yield } \\
\mathrm{kg} / \\
\text { plot }\end{array}$ \\
\hline Seeds soaked in ascorbic acid & 103.0 & 3.2 & 19.2 & 71.8 & 1.84 \\
\hline Seeds soaked in shikimic acid & 105.0 & 3.2 & 15.2 & 70.0 & 1.82 \\
\hline Seeds coated with Plant Guard & 110.0 & 3.2 & 18.0 & 72.0 & 1.87 \\
\hline Seeds coated with Rhizo-N & 105.0 & 3.0 & 17.0 & 70.1 & 1.75 \\
\hline $\begin{array}{l}\text { Seeds soaked in ascorbic acid and } \\
\text { coated with Plant Guard }\end{array}$ & 115.0 & 3.8 & 19.2 & 75.3 & 1.93 \\
\hline $\begin{array}{l}\text { Seeds soaked in ascorbic acid and } \\
\text { coated with Rhizo-N }\end{array}$ & 110.0 & 3.5 & 19.0 & 73.0 & 1.89 \\
\hline $\begin{array}{l}\text { Seeds soaked in shikimic acid } \\
\text { and coated with Plant Guard }\end{array}$ & 109.0 & 3.4 & 18.0 & 74.0 & 1.90 \\
\hline $\begin{array}{l}\text { Seeds soaked in shikimic acid } \\
\text { and coated with Rhizo-N }\end{array}$ & 106.0 & 3.4 & 17.2 & 72.0 & 1.85 \\
\hline $\begin{array}{l}\text { Seeds dressed with the fungicide } \\
\text { Rizolex-T }\end{array}$ & 110.0 & 4.0 & 21.0 & 76.1 & 1.97 \\
\hline Control (untreated) & 102.0 & 1.7 & 13.7 & 65.0 & 1.42 \\
\hline L.S.D at 5\% & 3.1 & 1.0 & 2.1 & 1.9 & 18.0 \\
\hline
\end{tabular}

Effect of the tested bioproducts, IRCs and Rizolex-T on total nitrogen and protein constitutes of faba bean dry seeds:

Data presented in Table 5 show that all the tested treatments significantly increased total $\mathrm{N}$ and crude protein content in faba bean seeds compared with untreated treatments. Also, the combination between ascorbic acid and Plant Guard recorded the highest total $\mathrm{N}$ and crude protein followed by the combination between shikimic acid and Plant Guard in both seasons. Meanwhile, both shikimic acid and Rhizo- $\mathrm{N}$ individually recorded the lowest increase in this respect. 
Table 4b. Effect of the tested bioagents, IRCs and the fungicide Rizolex-T on some crop parameters of faba bean plants under field conditions during 2015/2016 growing season

\begin{tabular}{|c|c|c|c|c|c|}
\hline Treatment & $\begin{array}{l}\text { Plant } \\
\text { height } \\
(\mathrm{cm})\end{array}$ & $\begin{array}{c}\text { No. of } \\
\text { branches } \\
\text { / plant }\end{array}$ & $\begin{array}{l}\text { No. of } \\
\text { Pods/ } \\
\text { plant }\end{array}$ & $\begin{array}{l}\text { Weight } \\
\text { of } 100 \\
\text { seed }(\mathrm{g})\end{array}$ & $\begin{array}{l}\text { Seed yield } \\
(\mathrm{kg}) / \text { plot }\end{array}$ \\
\hline Seeds soaked in ascorbic acid & 100.0 & 3.1 & 17.0 & 70.0 & 1.80 \\
\hline Seeds soaked in shikimic acid & 104.0 & 3.1 & 13.3 & 72.0 & 1.78 \\
\hline Seeds coated with $T$. harzianum & 106.0 & 3.1 & 17.0 & 71.1 & 1.83 \\
\hline Seeds coated with $B$. subtilis & 103.0 & 2.9 & 16.2 & 69.2 & 1.70 \\
\hline $\begin{array}{l}\text { Seeds soaked in ascorbic acid and } \\
\text { coated with } T \text {. harzianum }\end{array}$ & 112.0 & 3.4 & 18.9 & 73.2 & 1.90 \\
\hline $\begin{array}{l}\text { Seeds soaked in ascorbic acid and } \\
\text { coated with } B \text {. subtilis }\end{array}$ & 107.0 & 3.2 & 18.7 & 71.0 & 1.85 \\
\hline $\begin{array}{l}\text { Seeds soaked in shikimic acid and } \\
\text { coated with } T \text {. harzianum }\end{array}$ & 106.0 & 3.3 & 16.0 & 72.0 & 1.89 \\
\hline $\begin{array}{l}\text { Seeds soaked in shikimic acid and } \\
\text { coated with } B \text {. subtilis }\end{array}$ & 102.0 & 3.3 & 15.4 & 69.9 & 1.81 \\
\hline $\begin{array}{l}\text { Seeds dressed with the fungicide } \\
\text { Rizolex-T }\end{array}$ & 109.0 & 4.0 & 20.1 & 75.0 & 1.93 \\
\hline Control (untreated) & 99.0 & 1.3 & 12.6 & 63.0 & 1.38 \\
\hline L.S.D at $5 \%$ & 3.0 & 0.9 & 2.0 & 1.7 & 17.3 \\
\hline
\end{tabular}


Table 5. Percentages of total nitrogen and protein constitutes of faba bean dry seeds as affected by the tested IRCs, bioagents and the fungicide Rizolex-T during 2014/2015 and 2015/ 2016 growing seasons

\begin{tabular}{|l|c|c|c|c|}
\hline \multirow{2}{*}{ Treatments } & \multicolumn{2}{|c|}{$2014 / 2015$} & \multicolumn{2}{c|}{$2015 / 2016$} \\
\cline { 2 - 5 } & $\begin{array}{c}\% \\
\text { Total } \\
\text { Nitrogen }\end{array}$ & $\begin{array}{c}\% \\
\text { Protein }\end{array}$ & $\begin{array}{c}\% \\
\text { Total } \\
\text { Nitrogen }\end{array}$ & $\begin{array}{c}\% \\
\text { Protein }\end{array}$ \\
\hline Seeds soaked in ascorbic acid & 4.20 & 26.25 & 3.98 & 24.88 \\
\hline Seeds soaked in shikimic acid & 4.10 & 25.63 & 3.90 & 24.38 \\
\hline Seeds coated with T. harzianum & 4.19 & 26.19 & 4.10 & 25.63 \\
\hline Seeds coated with B. subtilis & 4.02 & 25.13 & 3.95 & 24.69 \\
\hline $\begin{array}{l}\text { Seeds soaked in ascorbic acid and } \\
\text { coated with T. harzianum }\end{array}$ & 5.18 & 32.38 & 4.15 & 25.94 \\
\hline $\begin{array}{l}\text { Seeds soaked in ascorbic acid and } \\
\text { coated with }\end{array}$ & 4.95 & 30.94 & 4.80 & 30.00 \\
\hline $\begin{array}{l}\text { Seeds soaktilis } \\
\text { and coated with T. harzianum }\end{array}$ & 4.80 & 30.00 & 4.60 & 28.75 \\
\hline $\begin{array}{l}\text { Seeds soaked in shikimic acid } \\
\text { and coated with B. subtilis }\end{array}$ & 4.60 & 28,75 & 4.30 & 26.88 \\
\hline $\begin{array}{l}\text { Seeds dressed with the fungicide } \\
\text { Rizolex-T }\end{array}$ & 4.30 & 26.87 & 4.20 & 26.25 \\
\hline Control (untreated) & 3.95 & 24.69 & 3.70 & 23.13 \\
\hline L.S.D at 5\% & 0.29 & 2.41 & 0.35 & 2.35 \\
\hline
\end{tabular}

\section{Dis c us s i o n}

Plant growers are interested in reducing dependence on chemical inputs. Therefore, disease management should rely more on principles of Integrated Pest Management (IPM) such as sanitation, biological control, resistant cultivars, induced disease resistance. In this regard, model describing the several steps required for a successful IPM has been developed by Mc Spadden and Fravel (2002), where modern agriculture and horticulture must combine several objectives that seem to be almost mutually exclusive: to satisfy the nutritional needs of an increasing human population and to minimize the negative impact on the environment. In addition, the environmental pollution caused by excessive use and misuse of agrochemicals, as well as fear-mongering by some opponents of pesticides, has led to considerable changes in people's attitudes towards the use of pesticides in agriculture. Nowadays, there are strict regulations on chemical pesticide use. Additionally, the spread of plant diseases in natural ecosystems may preclude successful application of chemicals, because of the scale to which such applications might have to be applied. Consequently, some pest management researchers have focused their efforts on developing alternative inputs to synthetic chemicals for controlling pests and diseases. Among these alternatives are those referred to as biological controls (Pal and Mc Spadden, 2006).

Egypt. J. Phytopathol., Vol. 45, No. 1 (2017) 
It is known that chemical pesticides are highly effective and convenient to use but they are a potential threat for the environment and all kinds of life on earth. Therefore, the use of biological control agents for the management of plant pathogens is considered as a safer and sustainable strategy for safe and profitable agricultural productivity. Bacillus-based biocontrol agents play a fundamental role in the field of biopesticides. Many Bacillus species have proved to be effective against a broad range of plant pathogens. They have been reported as plant growth promoter, systemic resistance inducer, and used for production of a broad range of antimicrobial compounds (lipopeptides, antibiotics and enzymes) and competitors for growth factors (space and nutrients) with other pathogenic microorganisms through colonization (Shafi et al., 2017).

Soil-borne diseases of faba bean including damping-off, root-rot and / or wilt cause considerable loss to the plant stand and the yield. On the other hand, biological control of root diseases is largely based upon competition between the bioagents and the pathogens. Competitive colonization of the rhizosphere by the bioagents and the use of available resources are thought to exclude many rhizosphere soil-borne pathogens (Mc Spadden and Fravel, 2002). The mechanism of systemic acquired resistance is apparently multifaceted, likely resulting in stable broad-spectrum disease control that could be used preventatively to bolster general plant health, and resulting in long lasting protection (Kessmann et al., 1994).

The obtained data in vitro revealed that both bioagents ( $T$. harzianum and B. subtilis), IRCs (ascorbic and shikimic acid) and the fungicide Rizolex-T caused significant reduction to the linear growth of the three pathogenic fungi, i.e. $F$. moniliforme, $F$. solani and M. phaseolina. Also, these treatments caused significant reduction to pre- and post-emergence damping-off as well as root-rot severity and increased the survived plants either in greenhouse or in field experiments, compared to the control. The combination between any of the two IRCs and any of the two bioproducts was more effective in this regard than when each of them was used individually. The combination between ascorbic acid and Plant Guard recorded the highest efficiency in this respect. These results are in agreement with those reported by Abd-Alla (1994). Seeds soaked in any of the IRCs and coated with any of the two bioproducts (Plant Guard and Rhizo-N) resulted in significant reduction to damping-off and root-rot diseases during the growing seasons of 2014/2015 and 2015/2016 with considerable increase to the assessed crop parameters as well as considerable increase in the percentages of total nitrogen and protein constitute in the dry faba bean seeds. Similar results were obtained by Rajkumar et al. (2008); Morsy (2011) and Yobo et al. (2011).

Gram-positive Bacillus species, however, possess several advantages that make them good candidates for use as biological control agents (BCA). First, their antagonistic effect is caused by their ability to produce different types of antimicrobial compounds, such as antibiotics e.g., bacilysin, iturin, mycosubtilin and siderophores (Shoda, 2000). Second, they are able to induce growth and defense responses in the host plant (Raupach and Kloepper, 1998). Furthermore, Bacillus is able to produce spores resistant to UV light and desiccation, which Egypt. J. Phytopathol., Vol. 45, No. 1 (2017) 
allows them to resist adverse environmental conditions, and permits easy formulation for commercial purposes (Raaijmakers et al., 2002).

It is supposed that Bacillus spp. could be have diverse plant response involved in synthesis and accumulation of antimicrobial phytoalexins (Hammond-Kosack and Jones, 1996), induction of hypersensitive response (He et al.,1993), production of defense-related proteins (Yu,1995) production of activated oxygen species (Baker et al.,1993), and modification of plant cell wall by deposition of callose (Veit et al., 2001).Also, Xing et al.(2003) declared that Bacillus spp. grow very fast and occupy the court of infection preventing pathogen spores to reach susceptible tissues in competition for spaces. This might be due to that treatments with biopreparation induce systemic resistance as the main mechanism of activity on the plant. Moreover, Bacillus species have a unique ability to replicate rapidly, resistant to adverse environmental conditions as well as they have broad spectrum of biocontrol ability. Volatile compounds produced by B. subtilis also play an important role in plant growth promotion and activation of plant defence mechanism by triggering the induced systemic resistance (ISR) in plants (Compant et al., 2005).

Trichoderma spp. are the most promising and effective bioagents against various plant pathogenic fungi. Trichoderma as antagonist for controlling wide range of microbes was well documented and demonstrated for more than seven decades ago but its use under field conditions came much later (Ragab et al.,2015) and their mechanism of mycoparasitism is much more complex, that is nutrient competition, hyperparasitism, antibiosis, space and cell wall degrading enzymes (Abd-El-Khair et al., 2010). Trichoderma spp. are known to control pathogens either indirectly by competing for nutrients and space, modifying the environmental conditions, or promoting plant growth and enhancing plant defensive mechanisms and antibiosis, or directly by inhibition of growth and sporulation of the pathogen mechanisms such as mycoparasitism and enzyme production (Bouhassan et al., 2004, Faheem et al., 2010 and Ragab et al., 2015). El-Mougy et al. (2013) reported an announced reduction in root-rot incidence of bean and cowpea, caused by the pathogens $R$. solani and $F$. solani that was achieved using of $T$. harzianum.

Biological control of damping-off diseases has been successfully applied using B. subtilis (Harris and Adkins 1999 and Schmidt et al., 2004) and T. harzianum (Ragab et al.,2015 and Ahmed, 2016). In this respect, Trichoderma spp. are known to control pathogens either indirectly by competing for nutrients and space, modifying the environmental conditions, or promoting plant growth and enhancing plant defensive mechanisms and antibiosis, or directly by inhibition of growth and sporulation of the pathogen mechanisms such as mycoparasitism and enzyme production (Zimand et al., 1996 and Bouhassan et al., 2004).

Abd-Alla (1994) concluded that phenolic compounds at low concentration (100 $\mu \mathrm{M})$ can be used to improve soybean crop performance by stimulating nodulation, plant growth and ammonia assimilation. In addition, the results obtained here are in agreement with the results of Aldesuquy and Ibrahim (2000) who stated that seed priming with shikimic acid increased growth and yield of cowpea plants grown

Egypt. J. Phytopathol., Vol. 45, No. 1 (2017) 
under greenhouse conditions through increasing the total soluble sugars, protein content and photosynthetic activity. Application of antioxidants, e.g. ascorbic, salicylic, cumaric, benzoic acids and propylgalate as either seed soaking or soil drench proved sufficient protection against cumin diseases caused by Fusarium oxysporum f. sp. cumini and Acremonium egyptiacum (Mostafa, 2006).

Ascorbic acid (vitamin-C) plays an important role as an antioxidant and protects the plant during oxidative damage by scavenging free radicals and ROS that are generated by various stresses (Schulthesis et al., 2002 and Elwan and El-Hamahmy, 2009). Higher content of ascorbic acid might maintains relatively lower levels of ROS in pepper and tomato fruit resulting in less damage caused by ROS after stress. In addition, Reddy et al. (2005) reported that the increase in soluble nitrogen may be ascribed to increased hydrolysis of proteins. In addition, Khan et al. (2011) reported that ascorbic acid can act efficiently in plants as immunomodulators when applied at the appropriate concentration and the current stage of plant development. They added that, ascorbate is implicated in plant responses to biotic stresses and to undergo profound changes in plants interacting with pathogens.

\section{Con clusion}

In conclusion, priming faba bean seeds with any of ascorbic and shikimic acid, Plant Guard and Rhizo-N significantly reduced both damping-off and root-rot diseases with considerable improve to crop parameters and increase the percentages of total nitrogen and protein content in the dry seeds. In addition, the combination between any of the two IRCs and the two bioproducts was better treatment than using any of them individually.

\section{R e f e r e n c es}

Abd-Alla, M.H. 1994. Some phenolic compounds enhance nodulation and nitrogen fixation in a soybean / Bradyrhizobium japonicum system. Phyton. Ann. Rev. Bot., 33: 249-256.

Abdel-Kader, M.M.; El-Mougy, Nehal, S. and Lashin, S.M. 2011. Essential oils and Trichoderma harzianum as an integrated control measure against faba bean root-rot pathogens. J. Plant Prot. Res., 51: 306 - 313.

Abd-El-Khair, H.R.; Khalifa, K.M.; Haggag, Karima H.E. 2010. Effect of Trichoderma spp. on damping off diseases incidence, some plant enzymes activity and nutritional status of bean plants. J. Amer. Sci., 6 (9):486-497.

Abdel-Monaim, F.A. 2013. Improvement of bio-control of damping-off and root-rot of faba bean by salicylic acid and hydrogen peroxide. Microbiol., 41(1):47-55.

Ahmed, G.A. 2016. Efficiency of some antioxidants and bioagents in controlling Rhizoctonia damping-off of snap bean. Middle East J. App. Sci., 6(4):748-758.

Egypt. J. Phytopathol., Vol. 45, No. 1 (2017) 
Aldesuquy, H.S. and Ibrahim, H.A. 2000. The role of shikimic acid in regulation of growth, transpiration, pigmentation, photosynthetic activity and productivity of Vigna sinensis plants. Phyton., 40: 277-292.

Baker, C.J.; Orlandi, E.W. and Mock, N.M. 1993. Harpin, an elicitor of the hypersensitive response in tobacco caused by Erwinia amylovora, elicits active oxygen production in suspension cells. Plant Physiol., 102 (4):1341-1344.

Begum, M.M.; Sariah, M.; Puteh, A.B.; Zainal Abidin, MA; Rahman, M.A.; Siddiqui, Y. 2011. Field performance of bio-primed seeds to suppress Colletrichum truncotum causing damping-off and seedling stand of soybean. Biolog. Cont., 53(1): $18-23$.

Bouhassan, A.; Sadiki, M. and Tivoli, B. 2004. Evaluation of a collection of faba bean (Vicia fabae L.) genotypes originating from the Maghreb for resistance to chocolate spot (Botrytis fabae) by assessment in the field and laboratory. Euphytica, 135:55-62.

Chavan, J.K.; Kute, L.S.; Kadam, S.S.; 1989. Soybean. In: (Eds. Salunkhe, D.D.; Kadam, S.S.). CRC handbook of world food legumes. Boca Raton: CRC Press, pp. $223-245$.

Compant, S.; Duffy, B. and Nowak, J. 2005. Use of plant growth-promoting bacteria for biocontrol of plant diseases: principles, mechanisms of action, and future prospects. App. Environ. Microbiol., 71(9):4951-4959.

De Boer, W.; Gerads, S.; Klein, Gunnewick, P.J. and Modderman, R. 1999. Response of the chitinolytic microbial community to chitin amendments of dune soils. Boil. Fertil. Soils, 29: 170 - 177.

Elwan, M.W.M. and El-Hamahmy, M.A.M. 2009. Improved productivity and quality associated with salicylic acid application in greenhouse pepper. Scientia Hort., 122:521-526.

El-Mohamedy, S.R. and Abdel Alla, M.A. 2013. Bio-priming seed treatment for biological control of soil borne fungi causing root-rot of green bean (Phaseolus vulgaris L.). J. of Agric. Technol., 9 (3): 589 - 599.

El-Mohamedy, R.S.; Shafeek, M.R. and Rizk, Fatma, A. 2015. Management of root-rot diseases and improvement growth and yield of green bean plants using plant resistance inducers and biological seed treatments. J. of Agric. Technol., 11(5): $1219-1234$.

El-Mougy, Nehal S.; Abdel-Kareem,F.; Abdel-Kader, M.M. and Fatouh,Y.O. 2013. Long term effect of applied compost and bioagents as integrated treatment for controlling bean root rot disease in solarized soil under field conditions. Plant Pathol. Quaran., 3(1): 41-52.

Faheem, A.; Razdan, V.K.; Mohiddin, F.A.; Bhat, K.A.; Sheikh, P.A. 2010. Effect of volatile metabolites of Trichoderma spp. against seven fungal plant pathogens in vitro. J. Phytopathol., 2(10): 34-37.

Egypt. J. Phytopathol., Vol. 45, No. 1 (2017) 
Gomez, K.A. and Gomez, A.A. 1984. Statistical Procedures for Agricultural Research. New York: A Wiley Inter. Science Publication. 680 p.

Hafez, A. and Mikkelsen, D.S. 1981. Colorimetric determination of nitrogen for evaluating the nutritional status of rice. Сопотпи., 12 (1): 61- 69.

Hammerschmidt, R. 1999. Induced disease resistance: How do induced plants stop pathogens?. Physiol. Mol. Plant Pathol., 55, 77-84.

Hammond-Kosack, K. E. and Jones, J.D.G. 1996. Resistance gene-dependent plant defence responses. The Plant Cell, 8: 1773-1791.

Harris, A.R. and Adkins, P.G. 1999. Versatility of fungal and bacterial isolates for fungal and bacterial isolates for control of damping-off disease caused by Rhizoctonia solani and Pythium spp. Biological control: Theory and applications in pest management. Biol. Cont., 15: 10-18.

He, S.Y.; Huang, H.C. and Collmer, A. 1993. Pseudomonas syringae pv. syringae harpin Pss: a protein that is secreted via the Hrp pathway and elicits the hypersensitive response in plants. Cell, 73(7):1255-1266.

Kessmann, H.; Sataub, T.; Hofmann, C.; Meatzke, T. and Herzog, J. 1994. Induction of systemic acquired disease resistance in plants by chemicals. Ann. Rev. Phytopathol., 32: 439-459.

Khan,T.A.; Mazid, M. and Mohammad, F. 2011. Role of ascorbic acid against pathogenesis in plants. J. of Stress Physiol. and Biochemis., 7(3): 222-234.

Khlangwiset, P.; Shephard, G.S. and Wu, F. 2011. Aflatoxins and growth impairment. Crit. Rev. in Toxicol., 41: 740 - 755.

Mc Spadden, Gardener B.B. and Fravel, D.R. 2002. Biological control of plant pathogens: Research, commercialization, and application in the USA. Online. Plant Health Progress doi:10.1094/PHP-2002-0510-01-RV.

Mancini, V. and Romanazzi, G. 2014. Seed treatments to control seed borne fungal pathogens of vegetable crops. Pest Manag. Sci., 70: $860-868$.

Morsy, K.M.; Abdel-Monaim, M.F. and Mazen, M.M. 2011. Use of abiotic and biotic inducers in controlling fungal diseases and improving growth in alfalfa. Aust. J. Basic App. Sci., 5: 816 - 824 .

Mostafa, W.E.B., 2006. Studies on some Cumin Diseases. M.Sc. Thesis, Fac. Agric., Minia Univ.

Muthomi, J.W.; Otieno, P.E.; Chemining'wa G.N.; Nderitu, J.H. and Wagacha, J.M. 2007. Effect of legume root-rots pathogens and fungicide seed treatment on nodulation and biomass accumulation. J. Biol. Sci., 7:1163-1170. 
Nayaka, S.C.; Niron, Jana S.R.; Shankar, A.C. and Mortensen, C.N. 2004. Seed bio-priming with novel strain of Trichoderma harzianum for the control of toxigenic Fusarium verticllioides and Fumonisin in maize. Archives of Phytopathol. Plant Protec., 1-19.

Pal, K.K.; Mc-Spadden, B. and Gardener, B.B. 2006. Biological Control of Plant Pathogens. The Plant Health Instructor. DOI: 10.1094/PHI-A-2006-1117-02.

Raaijmakers, J.M.; Vlami, M. and de Souza, J.T. 2002. Antibiotic production by bacterial biocontrol agents. Antonie Van Leeuwenhoek, 81: 537-547.

Ragab, Mona M.M.; Abada, K.A.; Abd-El-Moneim, L. M. and Abo-Shosha, Yosra Z. 2015. Effect of different mixtures of some bioagents and Rhizobium phaseoli on bean damping-off under field condition. Inter. J. Sci. Eng. Res., 6(7):10991106.

Rajkumar, M.; Lee, K.J. and Freitas, H. 2008. Effects of chitin and salicylic acid on biological control activity of Pseudomonas spp. against damping-off of pepper. South Afr. J. Bot., 74:268 -273.

Raupach, G.S. and Kloepper, J.W. 1998. Mixtures of plant growth-promoting rhizobacteria enhance biological control of multiple cucumber pathogens. Phytopathology, 88 (11):1158-1164.

Reddy, M.N.; Sridevi, N.V. and Devi, M.C. 2005. Changes in the nitrogen fractions and amino acid metabolism of turmeric (Curcuma longa L.) roots infected with Fusarium solani. Plant Pathol. Bull., 14: 221-226.

Roby, D.; Gadelle, A. and Toppan, A. 1987. Chitin oligosaccharides as elicitors of chitinase activity in melon plants. Biochem. Biophys Res. Commun., 143: 885 892.

Saikia, R.; Singh, T.; Kumar, R.; Srivastva, J.; Srivastava, A.K.; Singh, K. and Arora, D.K. 2003. Role of salicylic acid in systemic resistance induced by Pseudomonas fluorescens against Fusarium oxysporum f.sp. ciceri in chickpea. Microbial Res., 158: 203 - 213.

Salt, G.A. 1982. Factors affecting resistance to root-rot diseases (Eds. Hawtin, G. and Webb, C.); faba bean improvement. ICARDA, Aleppo, Syria, 260-270.

Schmidt, C.S.; Agostini, F.; Leifert, C.; Killham, K. and Mullins, C.E. 2004. Influence of soil temperature and metric potential on sugar beet seedling colonization and suppression of Pythium damping-off by the antagonistic bacteria Pseudomonas fluorescens and Bacillus subtilis. Phytopathology, 94: 351- 363 .

Schulthesis, H.; Dechert, C.; Kogel, K.H. and Huckelhoven, R. 2002. A small GTPbinding host protein is required for entry of powdery mildew fungus into epidermal cells of barley. Plant Physiol., 128: 1447-1454.

Shafi, J.; Tian, H. and Ji, M. 2017. Bacillus species as versatile weapons for plant pathogens: A review. J. Biotechnol. Biotechnol. Equip., 31(3): 446-459.

Egypt. J. Phytopathol., Vol. 45, No. 1 (2017) 
Shoda, M. 2000. Bacterial control of plant diseases. J. Biosci. Bioeng., 89 :515-521.

Singh, A.K.; Bhatt, B.P.; Upadhyaya, A. and Kumar, S. 2012. Improvement of faba bean (Vicia faba L.) yield and quality through biotechnological approach: A review. Afr. J. Biotechnol., 11(87): 15264-15271.

Veit S.; Wörle, J.M.; Nürnberger T.; Koch, W. and Seitz, H.U. 2001. A novel protein elicitor (PaNie) from Pythium aphanidermatum induces multiple defense responses in carrot, arabidopsis, and tobacco. Plant Physiol., 127(3):832-841.

Xing, L.; Ding, Z.; Wenxiang, Y.; Li, D. and Daqun, L. 2003. A study on the effect of Bacillus on downy mildew of cucumber. Plant Protec., 29(4): 25-27.

Yobo, K.S.; Laing M.D. and Hunter, C.H. 2011. Effects of single and combined inoculations of selected Trichoderma and Bacillus isolates on growth of dry bean and biological control of Rhizoctonia solani damping-off. Afr. J. Biotechnol., 10: 8746 -8756.

Yu, L.M. 1995. Elicitins from Phytophthora and Basic Resistance in Tobacco. Proc. Natl. Acad. Sci. U S A., 92 (10): 4088-4094.

Zimand, G.; Elad, Y. and Chet, I. 1996. Effect of Trichoderma harzianum on Botrytis cinerea pathogenicity. Phytopathology, 86: 1255-1260. 


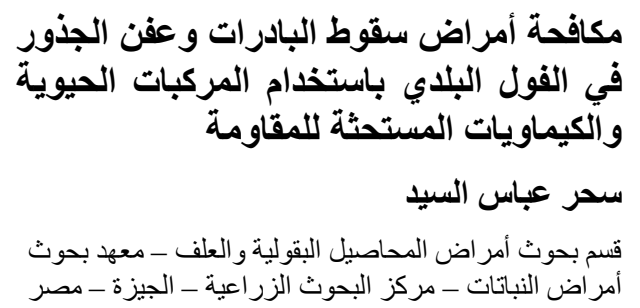

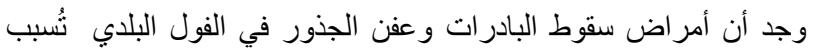

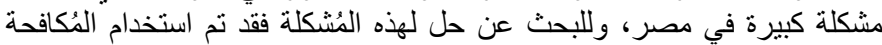

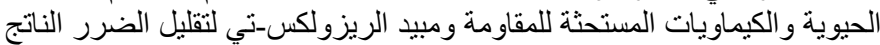

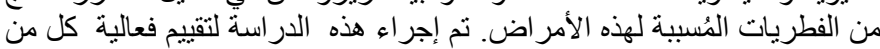

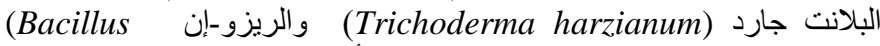

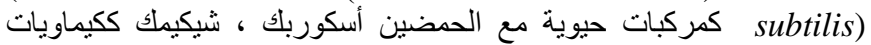

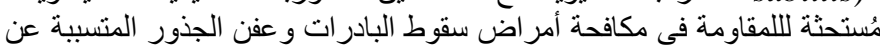
Fusarium moniliforme, F. solani and Macrphomina phaseolina

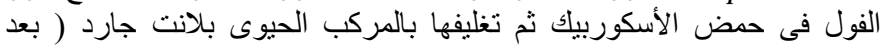

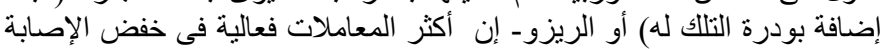

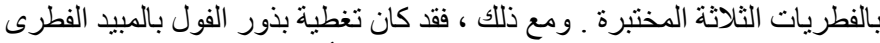

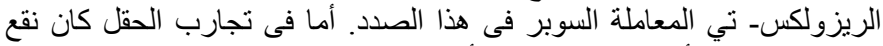

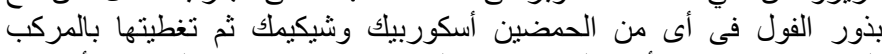

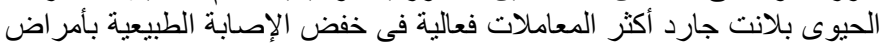

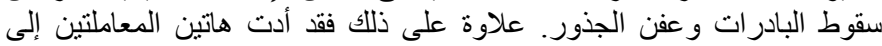

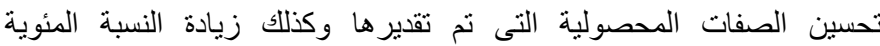

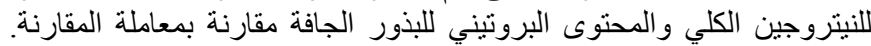

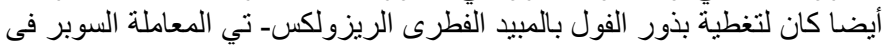

